\title{
519 視覚刺激に対する頭皮上および脳波事象関連電位パタン解析
}

\author{
Scalp Potential and ERP Pattern Analysis which Respond to Visual Stimuli
}

\author{
中尾友希（大崎電気）
}

Yuki NAKAO, Osakidenki

\section{○邊見佳輝（茨大工）}

Yoshiki HENMI, Ibaraki University

\section{正 住谷秀保（茨大工）}

Hideyasu SUMIYA, Ibaraki University

EEG contains a lot of information for activities such as human behavior and mental factors. Therefore, many studies about EEG have been made and many reported cases about this. However, measuring brain inside has many problems: the machines are large, expensive, and it takes time to process. Here, in this study, for EEG pattern discrimination interface construct with reproducibility, responsiveness, and verification by the closed-eye state for discrimination mechanism to focus on eye movement event-related potential, using Mahalanobis distance and a three-layer neural network. In addition, attempts to ICA of findings obtained by the scalp potential analysis by eye behavior.

Key Words: Eyeball, EOG, EEG, Mahalanobis distance, a three-layer neural network

\section{1. はじめに}

脳波は人の行動や精神活動などに対し多くの情報を含ん でいる. そのため, EEGに始まる脳機能野解析は基礎研究の みならずその応用についての開発例も数多く報告されてい る.しかし，脳内部を測定するためには大掛かりで，高価で あり，処理時間に時間を要するという問題がある。そこで本 研究では，再現性，即応性を有する脳波パタン判別インター フェイス構築のために眼球運動事象関連電位に着目し，マハ ラノビス汎距離判定や3 層ニューラルネットワークを用いた 判別機構について閉眼状態で検証を行った. また, 眼球動作 による頭皮上電位解析により得られた知見から独立成分分 析を試み, 同手法を用いた脳波抽出手法を提案した.

\section{2. システム概要}

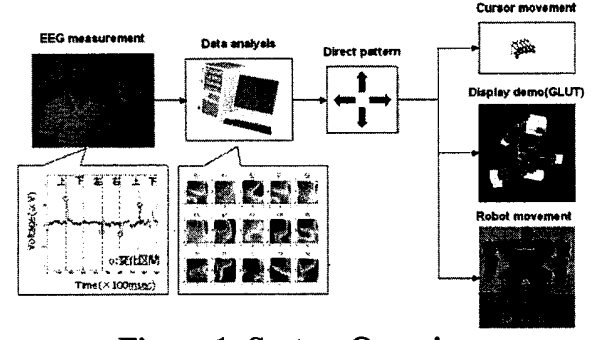

Figure 1: System Overview

脳波測定条件として被験者に閉眼状態で 5 秒ごとに送られ る「上, 左上, 左, 左下, 下, 右下, 右, 右上」の単音指示 に従い，眼球を動かしその状態を $2 \mathrm{~s}$ 間保つよう指示し，そ の後正面へ戻す指示を行った。
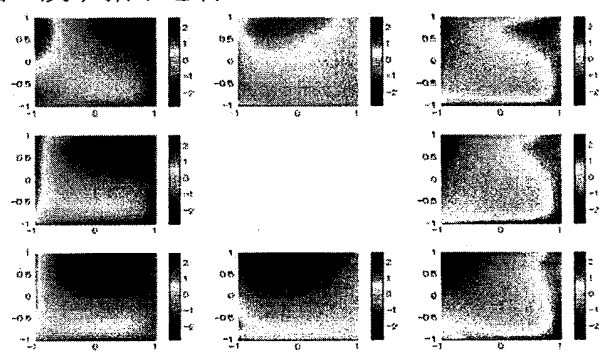

Figure 2: Reference Pattern

眼球動作による頭皮上電位により，ピーク発生時間 $660 \mathrm{~ms}$ が確認された. また, 解析より特徵パタンが指示後 $500 \mathrm{~ms}$ 後 から約 $1 \mathrm{~s}$ 間同じパタンを保持した後, ゆるやかに減衰し通
常の摇らぎパタンへ戻る変化を観測した.すべての被験者の 各方向に対し $500 \mathrm{~ms}$ から $1500 \mathrm{~ms}$ まで $7.8 \mathrm{~ms}$ 毎の類似パタン の加算平均基準パタンを求め判定機構を作成する. Figure 2 に頭皮上電位基準パタンを示す。

\section{ERP パタン利用眼球動作方向判定機楼}

脳波パタンから眼球動作に伴う $\mathrm{ERP}$ パタンを求め, 眼球 動作方向を判別する判定機構について検討する. 本報告で扱 う眼球動作関連頭皮上電位パタンは基本的に静的なべクト ルのパタン判別手法としており，(1)式で定義する.

$\mathrm{P}_{\mathrm{n}}=\left[\mathrm{p}_{1}, \mathrm{p}_{2}, \ldots, \mathrm{p}_{\mathrm{n}}\right]$

$=\left[\mathrm{ch}_{1}, \mathrm{ch}_{2}, \ldots, \mathrm{ch}_{\mathrm{n}}\right]$

$\mathrm{n}=[\mathrm{u}, \mathrm{ul}, \mathrm{l}, \mathrm{ll}, \mathrm{d}, \mathrm{lr}, \mathrm{r}, \mathrm{ur}]$

\section{1. マハラノビス汎距離判定}

解析対象データ $\mathrm{P}_{\mathrm{i}}$ と各参照パタンとの距離をので除した誤 差 值 $\mathrm{D}_{\mathrm{n}}(\mathrm{n}: \mathrm{u}, \mathrm{ul}, \mathrm{l}, \mathrm{ll}, \mathrm{d}, \mathrm{lr}, \mathrm{r}, \mathrm{ur})$ を式（2）で定義する (m: channel data, j: subject).

$\mathrm{D}_{\mathrm{n}}=\left\|\mathrm{P}-\mathrm{P}_{\mathrm{n}} / \sigma_{\mathrm{n}}\right\|_{2}$

$=\sqrt{\left(\frac{\mathrm{p}_{1}-\overline{\mathrm{p}}_{\mathrm{n} 1}}{\sigma_{\mathrm{n} 1 \mathrm{j}}}\right)^{2}+\cdots+\left(\frac{\mathrm{p}_{\mathrm{m}}-\overline{\mathrm{p}}_{\mathrm{nm}}}{\sigma_{\mathrm{nmj}}}\right)^{2}}$

判定対象に対し, 最も小さくなる $\mathrm{D}_{\mathrm{n}}$ よりパタン判定を行う.

3.2 ニューラルネットワーク判定

誤差逆伝搬法を利用し入力層 14 , 中間層 14 , 出力層 3 二 ニットのニューラルネットワークを Figure 3 のモデルのよう に構築する.

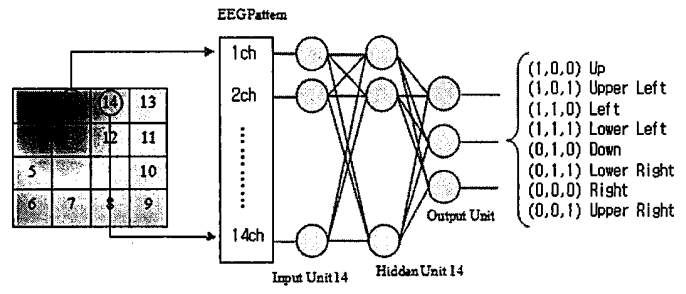

Figure 3: Neural Network Model

基準パタン $14 \mathrm{ch}$ を入力した際，出力が $(1,0,0)$ :上， $(1,0,1)$; 左上, $(1,1,0)$ :左, $(1,1,1)$ :左下, $(0,1,0)$ :下, $(0,1,1)$ : 右下, $(0,0,0)$ : 右, $(0,0,1)$ :右上となるようネットワークに学習させる. 学習 
が終わったネットワークに各被験者の脳波パタンを入力し, 出力値によって判定する.

\section{4. 判定結果}

判定手法による頭皮上電位変動点におけるパタン判別比 較結果を Figure 4 と Table 1 に示す。ママハラノビス汎距離判 定法では判定制度 80\%を示し, ニューラルネットワークを用 いた判定は 69\%の判定制度を示した. BMI 操作性向上のため 頭皮上電位変動時点の一瞬ではなく, 時間幅を有する場合の 判定率を検証する必要がある.マハラノビス汎距離判定法で は, 頭皮上電位変動点から $1 \mathrm{~s}$ 間, 3 層ニューラルネットワー ク判定では電位変動が安定する $700 \mathrm{~ms}$ からの $1 \mathrm{~s}$ 間で判定を 行った. パタン判別精度はマハラノビス汎距離判定法では $73 \% ， 3$ 層ニューラルネットワーク判定では $62 \%$ となり，と もに減少した。

判定の際，指示方向の隣接方向への誤判定が多く，隣接す る方向を同方向グループとみなし判定した結果を Table 1 に 示す．判定精度がともに $90 \%$ 程度と向上した。

これより, 新たな方向判別処理や手法の導入により，判別 精度と空間分解能向上の可能性がある.
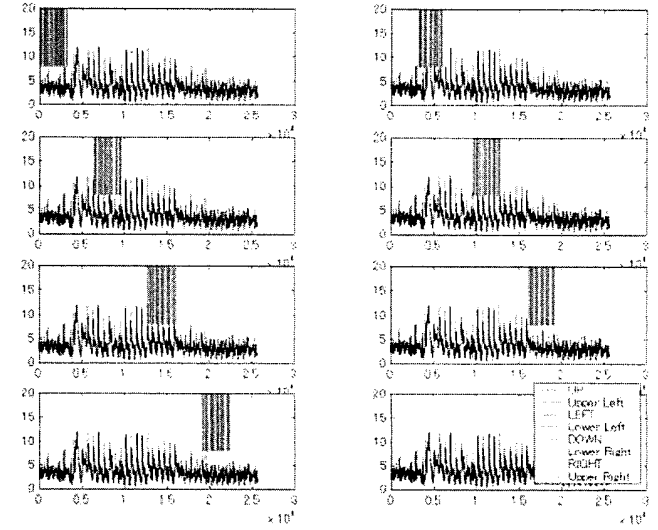

Figure 4: Result of the determination with MGD2

Table 1: Comparison of Discrimination Accuracy

\begin{tabular}{|c|c|c|c|c|}
\hline & \multicolumn{2}{|c|}{ Peak Point } & \multicolumn{2}{c|}{ Same Direction Group, 1s } \\
\hline Accuracy & MGD2 & M.N.N & MGD2 & M.N.N \\
\hline Subject A & $81 \%$ & $68 \%$ & $94 \%$ & $92 \%$ \\
\hline Subject B & $77 \%$ & $64 \%$ & $87 \%$ & $85 \%$ \\
\hline Subject C & $78 \%$ & $68 \%$ & $88 \%$ & $85 \%$ \\
\hline Subject D & $83 \%$ & $78 \%$ & $93 \%$ & $98 \%$ \\
\hline Average & $80 \%$ & $69 \%$ & $90 \%$ & $89 \%$ \\
\hline
\end{tabular}

\section{5. 事象関連電位抽出手法検討}

眼球動作事象関連電位抽出にはブラインド信号処理手法 の 1 つである独立成分分析(ICA)を用いた. ICA は原信号 $\mathrm{s}(\mathrm{t})$ と観測信号 $\mathrm{x}(\mathrm{t})$ は(3)式で定義され, 復元信号 $\mathrm{y}(\mathrm{t})$ は(4)式で定 義される. また, 今回用いた fastlCA 関数の更新則は(5)式で 定義される.

$\mathrm{x}(\mathrm{t})=\mathrm{As}(\mathrm{t})$

$\mathrm{y}=\mathrm{Wx}(\mathrm{t})$

$\widetilde{\omega}=\omega-\eta \frac{E\left\{x g\left(\omega^{T} x\right)\right\}-B \omega}{E g^{\prime}\left(\omega^{T} x\right)-B}$

$\frac{\widetilde{\omega}}{\|\widetilde{\omega}\|} \rightarrow \omega$

変数はそれぞれい:復元方向の正射影方向成分, $g\left(\omega^{\mathrm{T}} \mathrm{x}\right)$ :確率 密度関数, B:対角行列, $\mathrm{E}\left\{\mathrm{xg}\left(\omega^{\mathrm{T}} \mathrm{x}\right)\right\}:$ エントロピーである.

Subject A の上方向指示区間 $2 \mathrm{~s}$ 間に対しての ICA 実行例を Figure 5 に示す. 示していることから, 眼球動作関連電位で ある可能性がある。
fastICA は観測データ長が短いと独立成分の分解が困難な ため $2 \mathrm{~s}$ 閒の同一データを連続させて分析を行った.

ICA Components

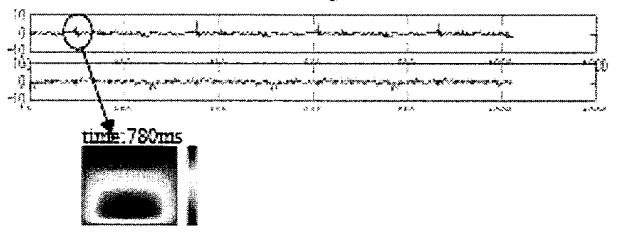

Figure 5: ICA Components and Montage(Subuject A)

また, ICA は初期值に乱数を用いるため, 試行回数によっ て結果が変動する.この試行の場合 $2 つ の$ 独立成分に分離で き，一方にピークが出現している. 眼球事象関連電位の抽出 のため, ピークの出現時間が頭皮上電位変動時点の近傍であ る独立成分に着目した. Figure 5 では独立成分のピークが $780 \mathrm{~ms}$ に出現しているのに対して, 頭皮上電位変動点は $870 \mathrm{~ms}$ であり, 上方向駆動時の頭皮上電位パタンと異なる電 位パタンを EOG, EMG が線形性を持つと仮定し, 頭皮上電 位参照パタンを用いた事象関連電位抽出手法を提案する.

Figure 6 に提案手法の流れを示す. 各指示方向に対応する参 照パタンの最大值を示すチャンネルを算出し, そのチャンネ ルを基準に元の波形との残差を取る. 残差に対して ICA を行 った. しかし，EOG，EMG 減衰部で残差が増加しており， EOG，EMG は線形性を持たず，近似させる必要があること が本解析によって明らかになった。

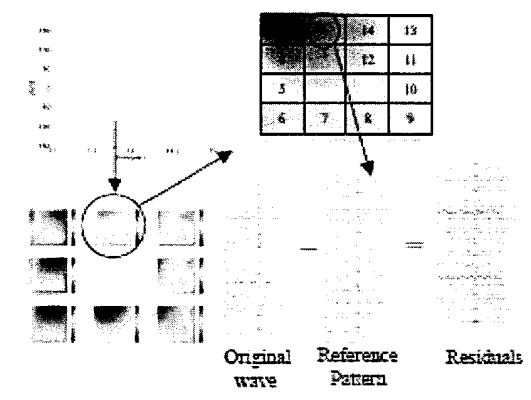

Figure 6: System Flow

\section{6. おわりに}

本報告では眼球運動事象関連電位を利用した脳波パタン 判別インターフェイスの判別手法について述べた. 8 方向の 眼球運動により誘発される頭皮電位パタンについて検討し, それぞれの方向の基準パタンを算出した. 判定精度はマハラ ノビス汎距離判定法で $80 \%, 3$ 層ニューラルネットワーク判 定で $69 \%$ となり，8 方向を判定可能であることを示した. ま た, ICA を用いた脳波事象関連電位抽出手法を提案した.

参考文献

(1)Kamitani,Y.Shimojo,S.Manifestationofscotomascreatedb ytranscranialmagneticstimulationofhu-manvisualcortex. NatureNeuroscience 2,767-771(1999)

(2)伊藤拓真, ” 実時間ロボット制御のための眼球駆動事象関 連電位パターン認識”，計測自動制御学会 (2009)

(3)KaiJ.Millera,MarceldenNijsa,PradeepShenoyc,JohnW.M illerd,RajeshP.N.RaoandJe_reyG.Ojemann,Real-timefu nctionalbrainmappingusingelectrocorticography,(1997)

(4)YukiyasuKamitani,FrankTong:"Decodingseenandattende dmotiondirectionsfromactivityinthehumanvisualcortex", CurrentBiology,16,1096-1102(2006).

(5)YukiyasuKamitani,FrankTong:"Decodingthevisualandsu bjectivecontentsofthehumanbrain",NatureNeuroscience $8,679-685(2005)$ 